\title{
The Myth of the Exploited Student-Athlete
}

\author{
Barbara Osborne \\ University of North Carolina at Chapel Hill
}

Check out ESPN, listen to "Mike and Mike" or any sports talk radio, and open any newspaper, and there will be a lot of buzz about student-athletes being forced into indentured servitude while the university makes millions off of them. Attacks against the NCAA seem to be coming from all directions - the media, the fans, the member schools, and past and present student-athletes. These complaints are also making their way into the legal system, with lawsuits and administrative actions filed claiming unfair rules, unfair compensation, unacceptable health risks and failure to educate. This essay examines and addresses the major criticisms of the current model of intercollegiate athletics, with a focus on claims that student-athletes are exploited because everyone else in college athletics is making money.

\section{The "Business" of College Sport}

The most repeated complaint about college athletics is that it is a "business" or "commercial activity." The NCAA reported \$797,598,000 in revenue for the 2012-2013 fiscal year (NCAAa, 2014). Television and marketing rights fees account for $90 \%$ of NCAA revenues, with championships ticket sales providing almost $9 \%$ and membership fees and other services accounting for less than 1\% (NCAAa, 2014). However, revenues paint only one-half of a budget picture. The NCAA is a voluntary membership, nonprofit organization. The national headquarters in Indianapolis and employees of the NCAA only exist to serve its members, the almost 1,100 colleges and universities that choose to join the association. Maintaining and managing the national office and providing services to the membership accounts for almost $20 \%$ of the NCAA's expenses (NCAAa, 2014). Another $16 \%$ of the budget is spent providing championships opportunities for student-athletes, and the remainder is distributed back to Division I members through their conferences (NCAAa, 2014). This places the NCAA squarely in the middle of nonprofit organizations relative to their mission-to-overhead spending ratio, with more than $80 \%$ of revenues going to support their mission. Some nonprofit organizations such as the American Red Cross do a little better, with approximately $92 \%$ of their income going to programming, but other well-respected nonprofits such as the American Cancer Society spend only $59 \%$ of its revenue on its charitable purpose (Delp, 2014).

Osborne is with the Department of Exercise and Sport Science, University of North Carolina, Chapel Hill, NC. Address author correspondence to Barbara Osborne at sportlaw@unc.edu. 
Corporate sponsorships, media rights, licensing, merchandise and ticket sales are also cited as "proof" of commercialization in college sport. Billions of dollars flow through college athletics programs-over $\$ 8$ billion dollars in revenue at 230 public institutions that are members of NCAA Division I (USA Today, 2014) — but this alone is not enough to categorize an athletics department as a commercial enterprise. In 2012-2103, the University of Texas reported income of $\$ 165,691,486$ (USA Today, 2014). While this is an incredible amount of money, other units on campus are also expected to generate significant amounts of income. No one is complaining about the millions of dollars generated by the chemistry department or the billions of dollars raised by the development office. Generating revenue is part of the business of education. The difference between a purely commercial model (professional sport) and the educational model is the purpose for generating revenue: in a commercial entity, the purpose is to make a profit, whereas in an educational institution, the purpose is to finance the opportunity for student-athletes to participate.

While billions of dollars flowed into Division I college athletics programs, billions are also being spent to provide athletics participation opportunities for student-athletes. Data provided by the NCAA reported only 20 Division I Football Bowl Subdivision (FBS) schools with revenues that exceeded their expenses (NCAAb, 2014). However, a USA Today database of 230 NCAA Division I public institutions revealed only seven athletics programs that did not receive some sort of subsidy from their institution (USA Today, 2014). The average net loss for Division I schools in the Big 5 conferences was $\$ 2.3$ million, and the remaining FBS institutions averaged a deficit of \$17.6 million (Burnsed, 2014).

Providing athletics participation opportunities is expensive, with the largest line items paying for salaries, direct sport expenses (travel, equipment, etc.), scholarships, facilities, and other administrative and support services such as sports medicine, academic support, strength and conditioning, nutrition, and sport psychology. Investment in goods and services that directly enhance the studentathlete's experience varies tremendously across institutions, but to claim that student-athletes only receive compensation in the form of tuition, room, board, books and fees grossly underestimates the overall tangible benefit of athletics participation.

The benefits that student-athletes receive (most commonly minimized by reference as only a scholarship) are often compared with coaches' salaries to establish that college athletics is a business and/or that student-athletes are undercompensated. Educational institutions, as nonprofit organizations, pay employees reasonable compensation for their efforts (World Family Corporation v. Comm'r, 1983). Although many may argue that paying a football or men's basketball coach a multimillion dollar salary-making the coach the highest paid employee on campus-is unreasonable, the legal determination of a reasonable salary is based on the market rate (Treas. Reg. $§ 1.162-7(b)(3), 2014)$. When considering total compensation, coaches' employment packages may not differ significantly from other superstar employees within the university such as doctors or scientists with supplemental income from grants or patents. In addition, paying a coach a high salary is another of the benefits that flows to student-athletes through their participation-it is the student-athlete who benefits from the coach's services; those highly paid coaches are often the reason student-athletes choose to attend that institution. 


\section{The Legal Relationship Between Student-Athlete and Institution}

The student-athlete/university relationship is primarily contractual in nature, as is the relationship between the university and its students (Mitten, Davis, Shropshire, Osborne \& Smith, 2012). When a student-athlete signs a financial aid agreement, she or he enters into a contractual relationship with the university whereby the institution promises to provide an athletics scholarship/financial aid in exchange for the student-athlete to participate in the college athletics program, stay academically eligible and follow institutional, conference, and national governing body rules (Mitten et al., 2012). Just as a financial aid agreement is calculated each year a student attends the institution, athletics scholarships have historically been valid for one year, renewable at the discretion of the institution. Criticisms that this relationship unfairly disadvantages student-athletes have led to new permissive NCAA legislation that allows institutions to offer multiyear scholarships (Bylaw 15.02.7, 2014). Multiyear scholarships do benefit student-athletes by allowing them to negotiate a guaranteed length for their potential value to any particular athletics program, and by providing security from annual scholarship nonrenewal due to disagreements with a coach or change in program direction when a new coach is hired. However, the potential risks of multiyear scholarships for student-athletes are rarely acknowledged. First, student-athletes still risk losing a multiyear scholarship contract if they are not academically eligible or break rules. Next, student-athletes who seek to transfer may find that their institution might not only refuse to issue a transfer waiver (as allowed by NCAA rules), but could seek a negative injunction prohibiting that player from competing for any other institution during the term of the multiyear scholarship as allowed by the courts for breach of contract (American Association Baseball Club v. Pickett, 1890; Cain v. Garner, 1916; Cincinnati Exhibition Co. v. Marsans, 1914; Madison Square Garden Corp. v. Camera, 1931; Philadelphia Ball Club v. Lajoie, 1902).

Participation in athletics is viewed as a privilege by the legal system. This is a concept that seems frequently forgotten. Student-athletes are not entitled to participate in college athletics; it is a privilege (with many benefits) to participate, and with privilege comes responsibility. If student-athletes are not happy with their situation as student-athletes, they do not have to participate.

\section{Student-Athlete Compensation}

The popular criticisms that student-athletes are being cheated in some way because the university is profiting from their labor and they don't get anything in return are ridiculous. All student-athletes are very well compensated for their participation, with $\$ 2.7$ billion in athletics scholarships provided to more than 150,000 studentathletes each year (NCAAc, 2014). Those student-athletes with full athletics scholarships have the value of a free education while the average student nationally graduates with $\$ 28,400$ of debt (Reed \& Cochrane, 2014), but all student-athletes, even walk-ons and those who only receive partial funding, benefit from coaching, facilities, clothing, and equipment for training and competition, travel experiences, and services received for academic support, strength and conditioning, sports 
nutrition, sports medicine, and even leadership training and life skills workshops. All of these experiences and services have value, with USA Today reporting a value of \$120,000 for Division I men's basketball players (Weiner \& Berkowitz, 2011). Rishe (2011) found that the "average value of a college football scholarship is in excess of \$2 million for student-athletes who (1) play for one of the pre-season Top 25 schools and (2) would not have pursued a college degree if it weren't for their scholarship" $(P 2)$. There are also intangible benefits developed or acquired through athletics participation such as leadership skills, the ability to work within a team toward a common goal, time management and task prioritization, and persistence, that have real value in the workplace and in life (Chalfin, Weight, Osborne, \& Johnson, in review; Plunkett, Weight, Osborne, \& Lancaster, in press; Weight, Navarro, Huffman, Smith-Ryan, in press).

Note that the term "student-athlete" is intended in its all-inclusive meaning. Most complaints about unfair treatment of student-athletes are really addressing only football and men's basketball, although these athletes make up less than seven percent of all student-athletes. In the O'Bannon v. NCAA (2014) lawsuit, Division I football and men's basketball players were able to certify as a class, and the plaintiffs' successfully argued that these student-athletes should be treated differently. From an equal protection model, an economic model, and most particularly the educational model (which is the world within which college athletics exists), football and men's basketball players should not be treated differently than any other student-athlete.

From an equal protection model, football players and basketball players practice and play games - the same as every other student-athlete on any other intercollegiate team. All student-athletes have demanding schedules that include classes, homework and/or study hall, practices, time in the training room for preventative and/or therapeutic purposes, strength and conditioning, competition and travel. Although football and men's basketball players are often taught from a young age that they are special, the only difference between them and the other student-athletes is that the sports they play are popular with the media and fans. Being able to compete in front of large crowds or on television is an additional intangible benefit that football and men's basketball players receive that others don't, but it shouldn't warrant entitlements for those athletes.

From an economic model, football players and men's basketball players already receive more in tangible benefits than most other student-athletes. These two sports on average constitute $78 \%$ of spending for men's sports in Division I (Fagan \& Cyphers, 2012). Football offers 85 full scholarships; this is the equivalent of $21 / 2-3$ full squads, depending on how you count special teams! This scholarship ratio also holds true for men's and women's basketball, but few other sports are allocated enough scholarship equivalents for even one complete starting lineup. Football and men's basketball teams also generally practice and play in the largest facilities, are coached by the best (definitely the best paid) coaches, and have dedicated strength and conditioning and sports medicine staff and facilities. Luxury locker rooms, big screen televisions in recreational lounges, and staying in hotel rooms the night before home games are all added benefits that these student-athletes receive that others don't. In Division III, football and men's basketball are allocated an average of $41 \%$ of men's athletics team budgets, an amount proportionate to the number of participation opportunities those sports offer. An economic model that treats football 
and men's basketball players the same as every other student-athlete would save athletics departments millions of dollars!

College athletics exists because it is an extension of the educational experience. In higher education, resources are allocated based on programming needs. Department allocations are generally based on the number of students in majors, not on how much money an academic department generates. Tuition is standardized for all students - students in English do not pay more tuition than students in Chemistry even though revenue generation through external grants is substantially higher in the sciences than the liberal arts. The educational model treats all students the same and utilizes institutional revenues across all programs. College athletics programs similarly, and appropriately, use all department revenues to provide opportunities for student-athletes in all sports.

\section{Student-Athletes Are Not Employees}

Although student-athletes are very well compensated (as previously discussed), compensation does not make them employees of the university. In March 2014, the Chicago Regional Director of the National Labor Relations Board (NLRB) issued a ruling granting scholarship football players at Northwestern University the right to collectively bargain under the National Labor Relations Act (NLRB Case 13-RC-121359, 2014). This decision was based predominantly on the conclusion that the football players met the definition of "employees" under Section 2(3) of the Act: “...[P]layers receiving scholarships to perform football-related services for the Employer under a contract for hire in return for compensation are subject to the Employer's control and are therefore employees within the meaning of the Act." Northwestern University has requested that the full National Labor Relations Board overturn the ruling because the regional director ignored key evidence and the congressional intent of the NLRA, misunderstood the cooperative educational relationship between the university and student-athletes and the primarily educational function of intercollegiate athletics (Northwestern University Brief, 2014).

Some will argue that football players with professional aspirations have to play college sport even if they are not interested in academics. First, from a legal perspective, attending college is always a choice-no one is legally forced to go. But even the small percentage of student-athletes who are primarily focused on a future professional career in sport are making a choice that is similar to that of all students attending colleges or universities. Students generally attend college seeking the opportunity to gain knowledge and skill that will help them succeed in a career and in life. The future pro chooses to participate in college athletics because he sees it as the best route to a professional career; the college experience is a better training ground and provides significantly greater visibility than other available alternatives. This is no different than any other student seeking a specific professional career opportunity. If a student desires a job in a particular career, for example medicine or engineering, they still have to take all university required courses before being eligible for that career field. Similarly, being eligible doesn't guarantee a career in that profession.

Aside from the Northwestern NLRB decision, past NLRB precedents as well as common law decisions indicate student-athletes are not employees (Coleman $v$. Western Mich. Univ., 1983; Rensing v. Ind. State Univ., 1983). First, a student-athlete cannot 
participate without being a student, maintaining academic eligibility, and making progress toward a degree. The time spent participating in athletics-related activities versus academics is arbitrary - there is wide fluctuation across the student body in the amount of time students spend in class and studying versus all other activities.

In the NLRB decision, an athletic scholarship is considered the equivalent of pay (Northwestern University and CAPA, 2014). By this logic, students who receive academic scholarships could also be considered employees just by attending class. Similarly, there is no logic in the decision that only scholarship football players are employees and therefore eligible to unionize, when walk-ons engage in exactly the same "work" activity by participating in football. By extension, all student-athletes in all sports should also be employees, because they all engage in the same "work." This is the premise of a lawsuit filed on October 20, 2014 in federal court by Samantha Sackos, a former college soccer player, against the NCAA and all Division I member institutions (Sackos v. NCAA, 2014). Relying on the definition of employee used by the NLRB in the Northwestern decision, Sackos claims that all student-athletes should be paid minimum hourly wages for their athletics participation, but that an athletics scholarship is not the equivalent of pay. While Sackos advocates that all student-athletes engage in the same activities, she fails to recognize that while student-athletes work hard at their sports, participation in athletics is not a job-it is an extracurricular activity. If a student-athlete doesn't feel that the benefits of athletics participation (tangible and intangible) are worth the time and effort expended engaged in that activity, then he or she can choose to participate in other activities!

The underlying premise of these cases is that student-athletes make all this money for the institution and/or the NCAA, and they get peanuts in return. First, student-athletes do not generate revenue. Student-athletes train and play games, whether anyone watches their performance on the court, field, pool, rink or track. Some sports attract more fans that are willing to watch their games, but spectators do not change the nature of what student-athletes do, nor does it turn those athletes into revenue generators. The sports are revenue generators, and athletic department employees in the ticket office, in marketing, and in athletics development/ fundraising generate revenue.

Criticisms that student-athletes (specifically football and men's basketball players) are not fairly compensated often make comparisons with other students who are paid for their skills or talent. Students who act, sing, or write are paid for their performances, right? Although these students may receive scholarships for their special talents, the institution does not invest significant amounts of resources beyond the classroom to develop those talents, nor do those students represent the university (on teams, in competition, wearing uniforms bearing the institution's name) the way that student-athletes do. Comparisons are also made with students who are paid for their participation in extracurricular activities such as student government or the campus newspaper; while these students may be paid, they typically do not receive scholarships or any other tangible benefits for the services they provide. These critics ignore the most obvious student comparison-the intern. It is well recognized that the best way to get a job in the sport industry is through an internship. There is little difference between the student-athlete and a sport management intern-both work long hours trying to gain skills that will make them more marketable in the workplace. 
In the Northwestern NLRB decision (2014), it was determined that scholarships were compensation; the Sackos complaint (2014) claims that scholarships are not appropriate pay. Rather than quibble about whether scholarships are the "compensation" that make student-athletes employees, a simple solution is to go nonscholarship. In the early days of the Association for Intercollegiate Athletics for Women (AIAW), athletic scholarships were prohibited because they put emphasis on athletics over academics, and the pressure to earn or keep a scholarship gave coaches undue power over student-athletes. Eliminating athletic scholarships would bring balance to the academics/athletics struggle and remove any indicia of payment to student-athletes. Funding no longer needed for athletics scholarships could be used to provide broader athletics participation opportunities. No one would lose current participation opportunities, as those with financial need could still receive financial aid. By eliminating the lure of college athletics scholarships, emphasis on athletics success in youth sport might be tempered as well.

Another alternative suggested relative to paying student-athletes is to let athletes negotiate their own compensation in a free market. These advocates of pay for play ignore that the current system (and even the nonscholarship system introduced in the preceding paragraph) already allows student-athletes to make free market decisions. Although NCAA rules limit how a student-athlete is compensated, it does not limit the value that the student-athlete receives. The value of an education, cost of tuition, room, board, books, fees, and cost of attendance, plus the bundle of athletics related benefits and services varies tremendously across institutions. Add to this the opportunity to negotiate multiyear scholarships (and possibly trust funds if the O'Bannon decision holds). Recruits evaluate all of these factors in choosing the school that best fits their needs.

Proponents of a free market system assume that football and men's basketball players would be paid more. While that is certainly a possibility if a free market was added to the current baseline, but in a true free market a very small number of elite athletes would be paid more, while the majority of football players would likely be paid less. The current system provides full scholarships for 85 football players and 13 men's basketball players. Some student-athletes on a football team may never play in a single game, and many will have very limited playing time-should this level of talent merit a full scholarship? A free market system that eliminates full scholarships and sets a team equivalency at the current 85/13 scholarship level for the football and men's basketball teams to better compensate the superstars would be preferred over eliminating participation opportunities overall to finance increased payments.

\section{The Burden of Receiving an Education is on the Student-Athlete}

Football players and men's basketball players have been taught that they are special, and that they are entitled to more than other athletes. But this mentality also short-changes them, because the cultural message they receive from the time they are relatively young is that athletic ability is more important than academic success. In our current economy, the value of a college degree has never been higher. Workers with a college degree earn $98 \%$ more per hour than those without, and 
are $75 \%$ less likely to be unemployed (Lowe, 2014). Putting all one's eggs in the athletics basket is a huge gamble. This is not just a college athletics problem-this is a societal problem.

In an ideal world, all student-athletes would value their academic experience at least equally with their athletics experience. The majority of student-athletes do care about their education and overall graduation rates for student-athletes are higher than nonathlete graduation rates (Brutlag Hosick, 2014). Unfortunately, some athletes assume that their special talent will compensate for any academic deficiencies, and this message is reinforced by the actions of some educators, coaches and administrators through middle school and high school. While possibly well intentioned, these individuals and those messages sell the athlete short. If the "reason" for passing someone through is to give them the opportunity to get a college scholarship, the scholarship is meaningless if they do not have the tools, skills, or mentality to do the work.

Fueled by the recent academic scandal at the University of North Carolina at Chapel Hill, some "reformers" are calling for the elimination of special admissions policies that allow recruits who do not meet institutional averages to be admitted. This is misguided because half of the students at any institution are admitted with credentials that are below average. Granted, institutions that admit student-athletes who are truly not capable of doing college level work are unethical, but if a special talent admissions committee truly believes that a recruit might be able to do the work if given the opportunity and appropriate academic support, shouldn't schools have the autonomy to make those decisions? From a public policy perspective, isn't it more discriminatory to eliminate an entire class of people from the opportunity to be educated, than to allow those who are perceived to have potential try, even if a few fall short along the way? Each institution should track their special admissions to see if their risks are paying off. Admitting student-athletes with academic deficiencies requires the institution to provide appropriate resources to assist them so that they can be academically successful. Note the distinction between this philosophy and end-goal compared with providing resources to keep at-risk student-athletes academically eligible to participate. Because it may be impossible on the surface to determine which philosophy student-athletes, coaches, tutors, or faculty buy into, the institution has a responsibility to put safeguards in place to promote the former and deter the latter.

One might argue that athletics-academic support programs would not be necessary if only those student-athletes who meet average university standards are admitted. I disagree. Programs that assist student-athletes with time management skills and provide tutoring to compensate for the amount of time athletes spend training and competing are reasonable. Again, the purpose for these programs cannot be to do the work for them or to allow them to major in eligibility. Academic counselors should not control student-athletes' choice of courses and/or majors. This creates restrictions that are not commensurate with the privilege of playing college athletics and countermands the purpose of being in college-to get an education.

Providing opportunities for academically at-risk student-athletes and appropriate academic support is only worthwhile if the student-athlete commits to being educated. The courts are very clear in this regard-the burden of receiving an education falls on the student. 


\section{Conclusion}

This is a critical moment in the history of college sport, and decisions that will impact the future of intercollegiate athletics need to be made carefully, thoughtfully and deliberately. While imperfect, the current system has provided opportunities for millions of student-athletes. The examples critics use illustrating problems with the current system are the exceptions, not the norm. Neither the exceptions, nor the demands of football and men's basketball players, should bring down the entire enterprise. If an athlete does not have the interest or intention of receiving an education, he or she should not participate in college athletics. College athletes are not hired as employees of the university—and they are not denied "free market" compensation for their athletic talents - they can take their talents to professional, semiprofessional, or developmental leagues. They do not have to play college athletics, and college athletics will survive without them. The opportunity to participate in college athletics requires participation in college education. These are the rules. If you don't like the rules, don't play!

\section{References}

American Association Baseball Club v. Pickett, 8 Pa. Co. Ct. Rep 232, 1890.

Brutlag Hosick, M. (2014). Student-athletes earn diplomas at record rate. Retrieved on Nov. 16, 2014 from http://www.ncaa.org/about/resources/media-center/news/studentathletes-earn-diplomas-record-rate

Burnsed, B. (2014, August). Growth in Division I athletic expenses outpaces revenue increases. Retrieved on Nov. 12, 2014 from http://www.ncaa.org/about/resources/ media-center/news/growth-division-i-athletics-expenses-outpaces-revenue-increases

Cain v. Garner, 169 Ky. 633 (1916).

Chalfin, P., Weight, E.A., Osborne, B., Johnson, S. (In Review - October, 2014). The value of intercollegiate athletics participation from the perspective of employers who target athletes.

Cincinnati Exhibition Co. v. Marsans, 216 Fed. 269 (D. Mo., 1914).

Coleman v. Western Mich. Univ., 336 N.W.2d 224 (Mich. Ct. App., 1983).

Delp, V. (2014). What percentage of donations go to charity. Retrieved on Nov. 10, 2014 from http://charity.lovetoknow.com/What_Percentage_of_Donations_Go_to_Charity

Fagan, K., \& Cyphers, L. (2012, April 29). Five Myths about Title IX. Retrieved on Nov. 12, 2014 from http://espn.go.com/espnw/title-ix/article/7729603/five-myths-title-ix

Lavigne, P. (2014, May). College sports thrive amid downturn. Retrieved on Nov. 10, 2014 from http://espn.go.com/espn/otl/story/_/id/10851446/sports-programs-nation-toppublic-colleges-thrived-economic-downturn-earning-record-revenues

Lowe, W.J. (2014, Sept. 4). Education is worth the investment. Retrieved on Nov. 16, 2014 from http://www.huffingtonpost.com/william-j-lowe/education-is-worth-thein_b_5767518.html

Madison Square Garden Corp. v. Camera, 52 F.2d 47 (2d Cir., 1931).

Mitten, M., Davis, T., Shropshire, K., Osborne, B., \& Smith, R. (2012). Sports Law: Governance and Regulation. New York: Wolters Kluwer.

NCAAa. (2014). The National Collegiate Athletic Association Revised Budget for Fiscal Year Ended August 31, 2013. Retrieved on Nov. 10, 2014 from https://www.ncaa.org/ sites/default/files/2012-13\%2BRevenue\%2Band\%2BExpense\%2BBudget.pdf

NCAAb. (2014). Revenues \& Expenses, 2004-2013 NCAA Division I Intercollegiate Athletics Programs Report. Retrieved on Nov. 10, 2014 from www.ncaapublications.com/ productdownloads/D1REVEXP2013.pdf 
NCAAc. (2014). The value of college sports. Retrieved on Nov. 10, 2014 from http://www. ncaa.org/student-athetes/value-college-sports

Northwestern University and College Athletes Players Association (CAPA). Case 13-RC121359, decided March 26, 2014. Retrieved on Nov. 16, 2014 from http://www.nlrb. gov/news-outreach/news-story/nlrb-director-region-13-issues-decision-northwesternuniversity-athletes

Northwestern University's Brief to the Board on Review of Regional Director's Decision and Direction of Election. Northwestern University and College Athletes Players Association (CAPA), Case 13-RC-121359, filed July 3, 2014. Retrieved on Nov. 16, 2014 from http:// dradis.ur.northwestern.edu/multimedia/pdf/nlrbappeal.pdf.\#sthash.8ZeCQx5z.dpuf

O'Bannon v. NCAA, C09-3329 CW, Findings of Fact and Conclusions of Law (USDC No. Dist. Cal., filed Aug. 8, 2014). Retrieved on Aug. 9, 2014 from http://www.nacua.org/ documents/Wilken-NCAA-Order_8-11-14.pdf

Philadelphia Ball Club v. Lajoie, 202 Pa. 210 (1902).

Plunkett, M.R., Weight, E., Osborne, B., \& Lancaster, E. (in press).The value of intercollegiate athletics participation from the perspective of former athletes. International Journal of Sport Management.

Reed, M., \& Cochrane, D. (2014). Student Debt and the Class of 2013. Retrieved on Nov. 12, 2014 from http://projectonstudentdebt.org/files/pub/classof2103_embargoed.pdf

Rensing v. Ind. State Univ., 444 N.E.2d 1170 (Ind. 1983).

Rishe, P. (2011, Aug. 21). Value of college football scholarship exceeds \$2 million for college football's top 25. Retrieved on Nov. 16, 2014 from http://www.forbes.com/ sites/prishe/2011/08/21/value-of-college-football-scholarship-exceeds-2-million-forcollege-footballs-top-25/

Sackos v. NCAA Complaint, Civil Action No. 1:14-CV-1710 WTL-MJD (United States District Court, Southern District of Indiana, Indianapolis Division, filed October 20, 2014).

Treas. Reg. § 1.162-7(b)(3).

USAToday (2014). NCAA athletic department revenue database. Retrieved on Nov. 10, 2014 from http://www.usatoday.com/sports/college/schools/finances/

Weight, E.A., Navarro, K., Huffman, L., \& Smith-Ryan, A. (in press).Quantifying the psychological benefits of intercollegiate athletics participation: Implications for higher education policy and practice. Journal of Issues in Intercollegiate Athletics.

Weiner, J., \& Berkowitz, S. (2011, March 30). USA Today analysis finds \$120k value in men's basketball scholarship. Retrieved on Nov. 16, 2014 from http://usatoday30.usatoday. com/sports/college/mensbasketball/2011-03-29-scholarship-worth-final-four_N.htm

World Family Corporation v. Comm'r, 81 T.C. 958, 969 (1983). 